\title{
An Analysis of the Vascular Flora of Annapolis Heathlands, Nova Scotia
}

\author{
S. CARbyn ${ }^{1}$, P. M. Catling ${ }^{2}$, S. P. VAnder Kloet ${ }^{3}$, and S. Basquill ${ }^{4}$ \\ ${ }^{1}$ Agriculture and Agri-Food Canada, Environmental Health, Biodiversity, 32 Main Street, Kentville, Nova Scotia B4N 1J5 \\ ${ }^{2}$ Agriculture and AgriFood Canada, Environmental Health, Biodiversity, Saunders Bldg., Central Experimental Farm, \\ Ottawa, Ontario K1A 0C6 Canada; e-mail: catlingp@agr.gc.ca \\ ${ }^{3}$ Department of Biology, Acadia University, Wolfville, Nova Scotia B4P 2R6 Canada \\ ${ }^{4}$ Atlantic Canada Conservation Data Centre, PO Box 6416, Sackville, New Brunswick E4L 1G6 Canada; e-mail: sbasquill@ \\ mta.ca
}

Carbyn, S., P. M. Catling, S. P. Vander Kloet, and S. Basquill. 2006. An analysis of the vascular flora of Annapolis Heathlands, Nova Scotia. Canadian Field-Naturalist 120(3): 351-362.

\begin{abstract}
A description and analysis of the vascular plant composition of heathlands in the Annapolis valley were undertaken to provide a basis for biodiversity preservation within a system of protected sites. Species presence and abundance were recorded at 23 remnant sites identified using topographic maps, air photos, and Nova Scotia Department of Natural Resources records. A total of 126 species was recorded, of which 94 were native and 31 introduced. The Annapolis heathland remnants are strongly dominated by Corema conradii with Comptonia peregrina, Vaccinium angustifolium and Pteridium aquilinum var. latiusculum. A number of species, including Solidago bicolor, Carex tonsa var. rugosperma, Dichanthelium depauperatum, Lechea intermedia, Melampyrum lineare, and Rubus hispidus, were characteristic of heathland remnants, although they usually contributed little to the total cover. The most frequent alien species were Hieracium pilosella and Festuca filiformis, but Pinus sylvestris, present at 7 of 18 sites, appeared to have the greatest impact in displacing native species. Species listed as at risk and sensitive in Nova Scotia, including Helianthemun canadense, Hudsonia ericoides and Viola sagittata var. ovata, occur in open disturbed sand in the Corema heathlands. Distinctive patterns of variation occur in several species and variation in crop relatives is noted with particular reference to the genera Rubus (blackberries), Amelanchier (Juneberries, Saskatoon) and Vaccinium (Blueberries). The available evidence suggests that the heathlands and sandy barrens in the Annapolis valley differ from those further west in Canada and from anthropogenic and coastal heathlands of Nova Scotia in their species composition including particularly the presence of Corema conradii, Hudsonia ericoides and Amelanchier lucida. The need to protect representative examples is supported.
\end{abstract}

Key Words: Heathlands, Annapolis valley, barrens, vascular plants, flora, Corema, Nova Scotia, Canada.

In 1921, legendary Harvard botanist Merritt Lyndon Fernald visited the Annapolis valley. He found extensive open heathlands. He noted: "near Berwick and from there to Wilmot were vast uncultivated plains carpeted, wherever dry enough, with a close growth of the New Jersey Pine barren Corema conradii, and, ... remnants of them near Middleton" (Fernald 1921). As recently as the 1960 s open heathlands with scattered Red Pines (Pinus resinosa) occurred for many miles along the Evangeline Trail (Figure 1). It has been estimated that in pre-settlement times the actual area of heathland encompassed approximately $200 \mathrm{~km}^{2}$. Today less than $3 \%$ of the original heathland vegetation remains in the Annapolis Valley (Catling et al. 2004), and even that is threatened by loss of natural ecological processes, invasive species and conversion of the landscape (Catling et al. 2004; Catling and Carbyn 2004). Protection of this ecosystem is important for the protection of (1) insect pollinators of adjacent crops; (2) protection of wild relatives of crops for crop improvement; (3) benchmark research examples; (4) teaching examples; (5) nature-related recreational opportunities; and (6) protection of biodiversity generally in connection with national and international accords. The only descriptions of Annapolis heathlands currently available (Fernald 1921; Roland 1946; Catling et al. 2004) are brief, non-quantitative, and insufficient as a basis for protection of biodiversity. Here we provide a description of remnants of natural heathland in the Annapolis Valley along with an indication of dominant species, rare and significant species, variation between sites and relationship to other eastern Canadian sand barrens. This is designed to provide a basis for further study and for the establishment of a system of protected sites.

\section{Methods}

\section{Sites and data}

The study area consists of 23 sites in the Annapolis Valley (Table 1, Figure 2). Sites are defined as areas surveyed separated by at least $0.5 \mathrm{~km}$. Information from the Nova Scotia Department of Natural Resources and topographical maps were used to determine the most probable locations of heathland vegetation occurring on sandy soil.

At sites 1-19 abundance of vascular plants was recorded. Areas surveyed varied from approximately $0.5-61$ hectares in extent. The majority of these 19 sites 


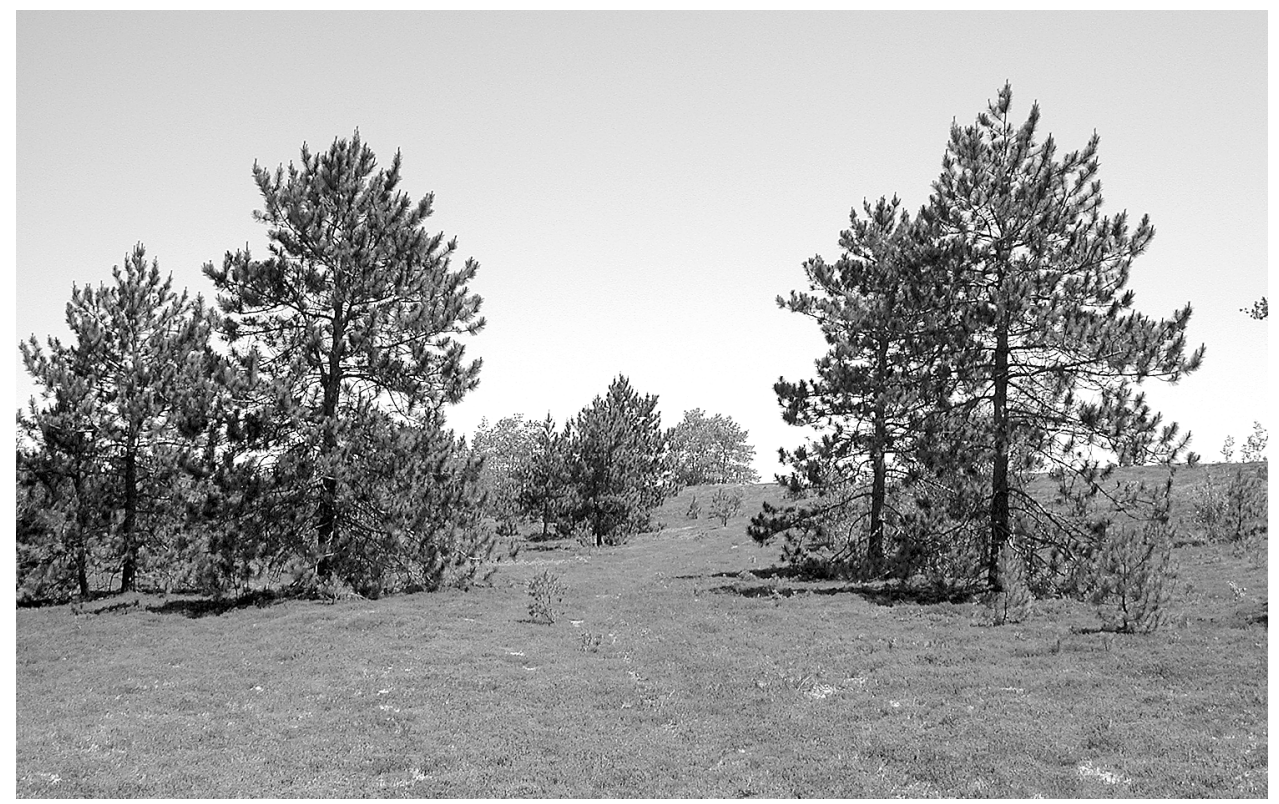

FIgURE 1. Open heathland dominated by Corema conradii (Broom Crowberry) with Pinus resinosa (Red Pine). Photo by P. M. Catling in 2004 at site 8.

were visited on at least two occasions in 2003 , with one visit in early summer and another in autumn. Approximately two hours were spent at each site on each visit. Species lists were made at each site (Table 2). An abundance value ranging from $0-5$ was assigned to each species $(1=$ rare, $2=$ uncommon, $3=$ com- mon, 4 = frequent and locally dominant, 5 = dominant) based on consensus of two or three observers. Although some larger sites were visited more often, almost all species recorded were recorded in the first hour of two visits. Time spent at sites was therefore considered to be adequate and the lists are thought to be essentially

TABLE 1. Site number and location of heathland study sites in the Annapolis Valley, Nova Scotia.

\begin{tabular}{|c|c|c|c|}
\hline \multicolumn{2}{|c|}{ Site Number, Name } & \multirow{2}{*}{\begin{tabular}{|c|} 
Latitude $^{\circ}$ \\
45.0059
\end{tabular}} & \multirow{2}{*}{\begin{tabular}{|c|} 
Longitude $^{\circ}$ \\
-64.8882
\end{tabular}} \\
\hline 1 & Evangeline Heathland E of 201 & & \\
\hline 2 & Evangeline Heathland W of 201 & 45.0048 & -64.8930 \\
\hline 3 & Trail Heathland & 45.0005 & -64.9004 \\
\hline 4 & Evangeline Main Heathland & 45.0094 & -64.8705 \\
\hline 5 & Brooklyn Street Wildlife Sanctuary & 45.0872 & -64.5245 \\
\hline 6 & Caribou Bog Heathland remnant & 45.0377 & -64.783 \\
\hline 7 & Trailer Park Heathland & 45.0219 & -64.8255 \\
\hline 8 & Exit 17 Heathland, NE corner & 44.9992 & -64.9411 \\
\hline 9 & Exit 17 Heathland, NW corner & 44.9962 & -64.9509 \\
\hline 10 & $4 \mathrm{~km} \mathrm{~W}$ of Middleton & 44.9204 & -65.1048 \\
\hline 11 & W side of Middleton & 44.9607 & -64.9999 \\
\hline 12 & Evangeline Cemetary & 44.9675 & -64.9866 \\
\hline 13 & E side of Greenwood Military Base & 44.9896 & -64.8955 \\
\hline 14 & Aldershot Military Base behind shooting range & 45.0966 & -64.5333 \\
\hline 15 & Greenwood section & 44.9833 & -64.8873 \\
\hline 16 & Exit 17 far east & 44.9974 & -64.9470 \\
\hline 17 & Greenwood Military Base main site & 44.9801 & -64.9381 \\
\hline 18 & Greenwood Military Base satellite & 44.9853 & -64.9308 \\
\hline 19 & 201 East near bog & 44.9791 & -64.9366 \\
\hline 20 & Plot - W of Whitman Road & 45.0109 & -64.8404 \\
\hline 21 & Plot $-\mathrm{E}$ of route 201 & 44.9992 & -64.8854 \\
\hline 22 & Plot $-\mathrm{N}$ of route 201 & 44.9472 & -65.0203 \\
\hline 23 & Plot $-\mathrm{S}$ of Ward Road & 44.9681 & -64.9367 \\
\hline
\end{tabular}




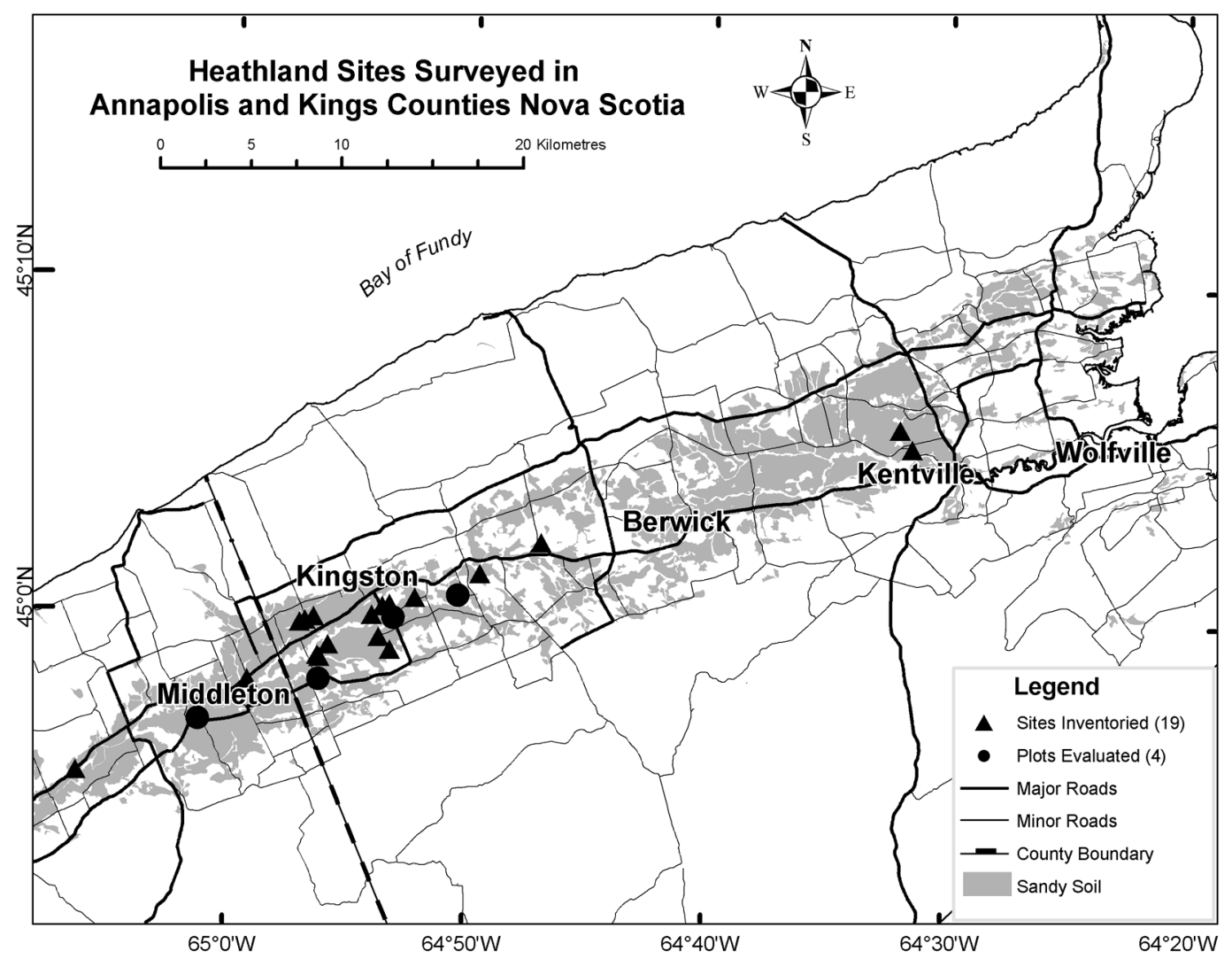

FIGURE 2. Heathland sites surveyed in the Annapolis Valley in 2004 (solid triangles) and location of plots evaluated for cover in 2005 (dots). The sandy soils of the valley (shaded) suggest the maximum extent of heathland.

complete. Voucher specimens collected at various sites were deposited in the vascular plant herbarium at Agriculture Canada in Ottawa (DAO). Status of plant species was determined by using Maher et al. (1978), the recent listing of species at risk (Nova Scotia Department of Natural Resources 2001*) and information and lists on file at the Atlantic Conservation Data Centre in Sackville.

At sites 20-23, plant association sampling methods were employed following provincial plot standards (Quigley et al. 2005*) and Canadian vegetation classification conventions (CNVC Technical Committee 2004*). In May of 2005, at each of the four sites, a four hundred square meter plot was subjectively placed in a homogeneous tract of heathland vegetation, where canopy tree cover exceeded 10 percent. The sampled association was the open woodland stage of the Annapolis Valley sand plain. Species and cover values, representing percentage of plot area within a vegetation layer, were visually assessed for five life forms (Table 3). Lichen names follow Esslinger (1997*), bryophyte names follow Anderson et al. (1990), and vascular plant names are from Kartesz and Meachum (1999).
Although many voucher specimens were collected (and deposited at DAO), a sufficient number of specimens of the genus Aronia were not collected to enable a determination of which species (or hybrid) was present at a particular site. Thus only the genus name appears in Table 2. Although Rosa carolina and Rosa virginiana were noted, both may have been present at any site where either was recorded, and some intermediates were noted. Rubus hispidus may be over-represented in the survey and Rubus arenicola may be under-represented due to difficulties in distinguishing these, and hybrids between them may also have been present.

\section{Results and Discussion.}

Native species and limitations of the vegetation description

Although 104 native species are recorded from the 23 sites surveyed, and although these sites covered a rather extensive area, they were mostly drier examples of dry, open sandy habitats (Figure 1). The relatively short-lived wetter examples and those associated with natural disturbances, such as fire, are now much less common than the drier examples. Thus as a reconstruc- 


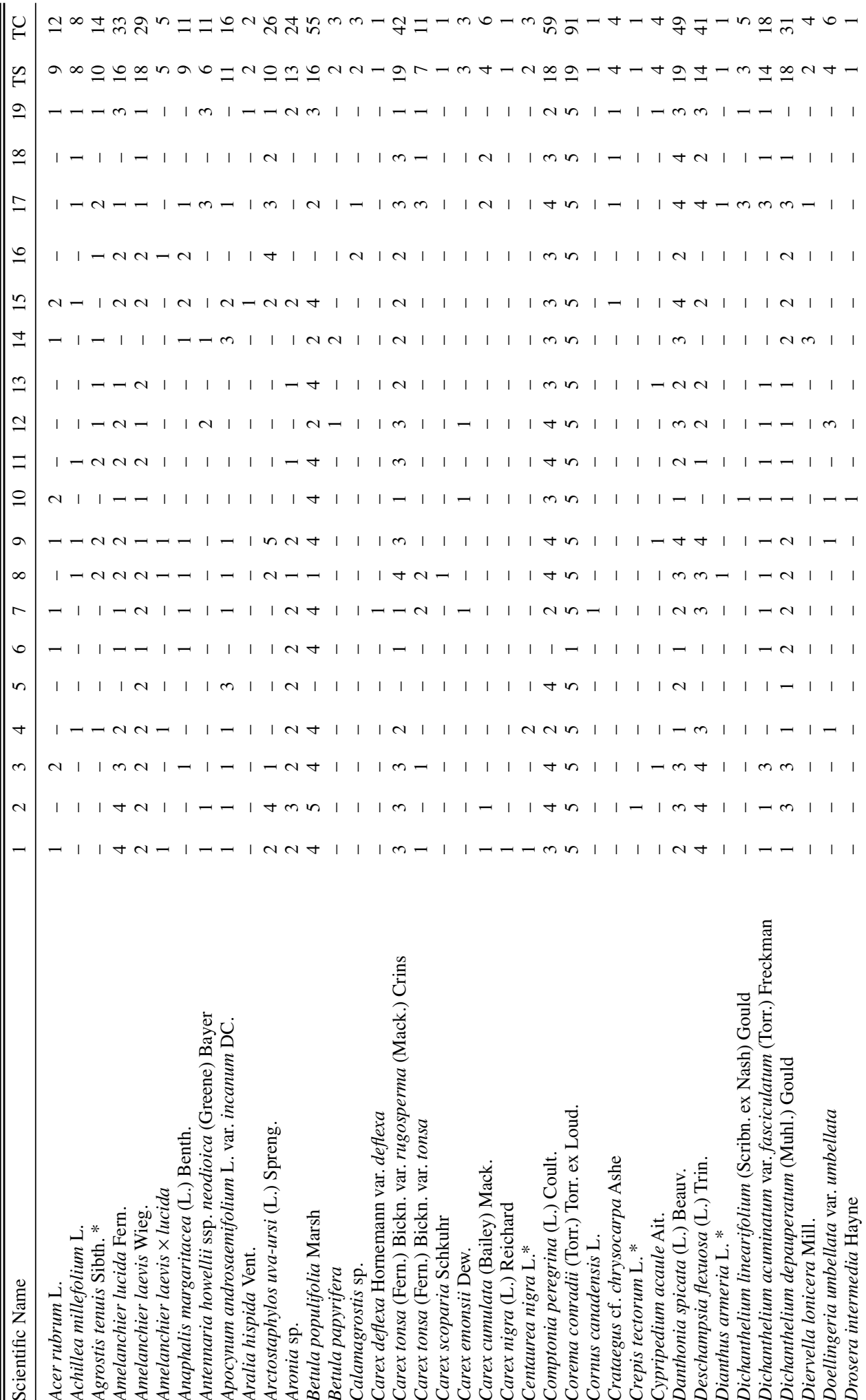




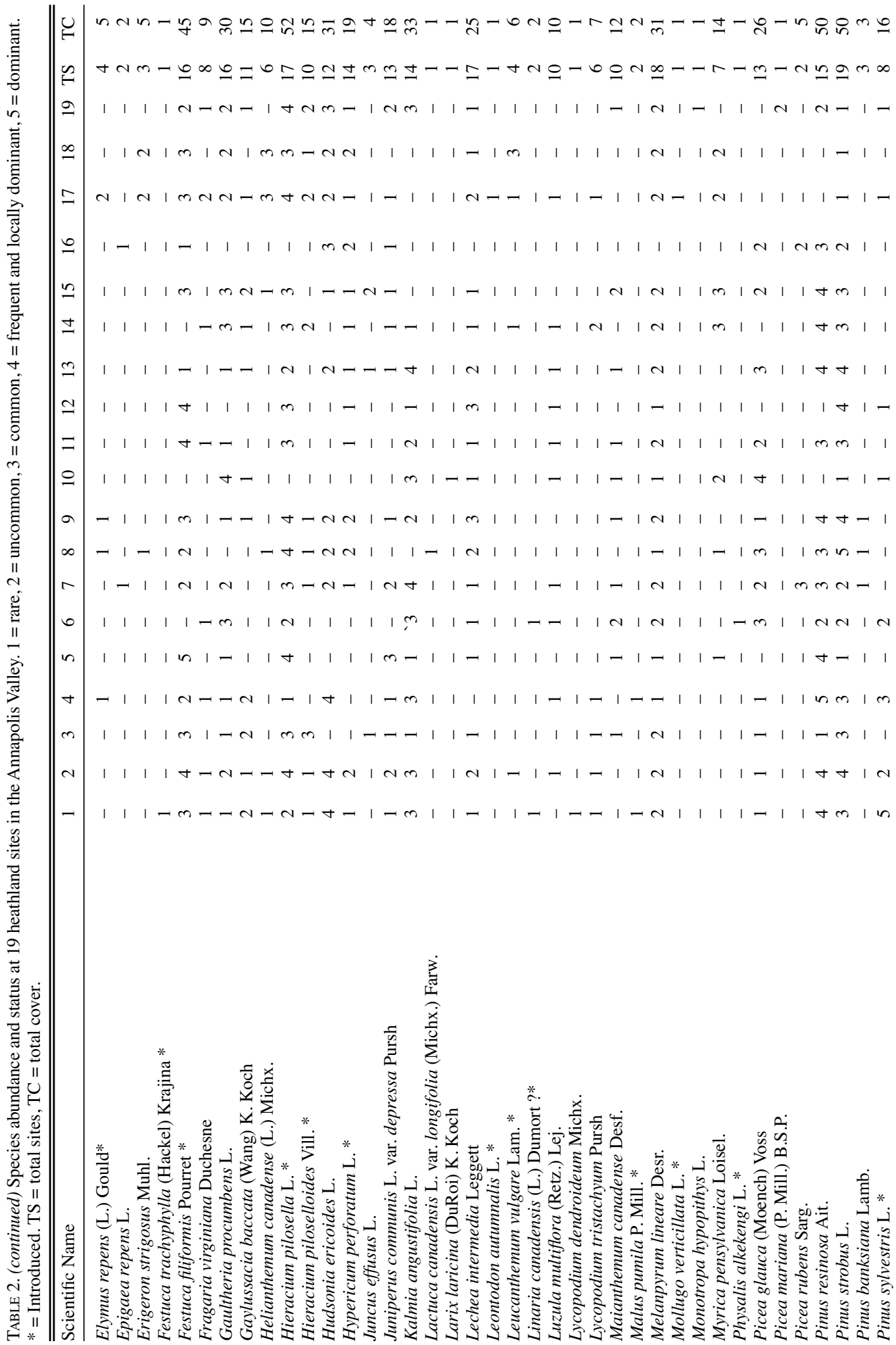




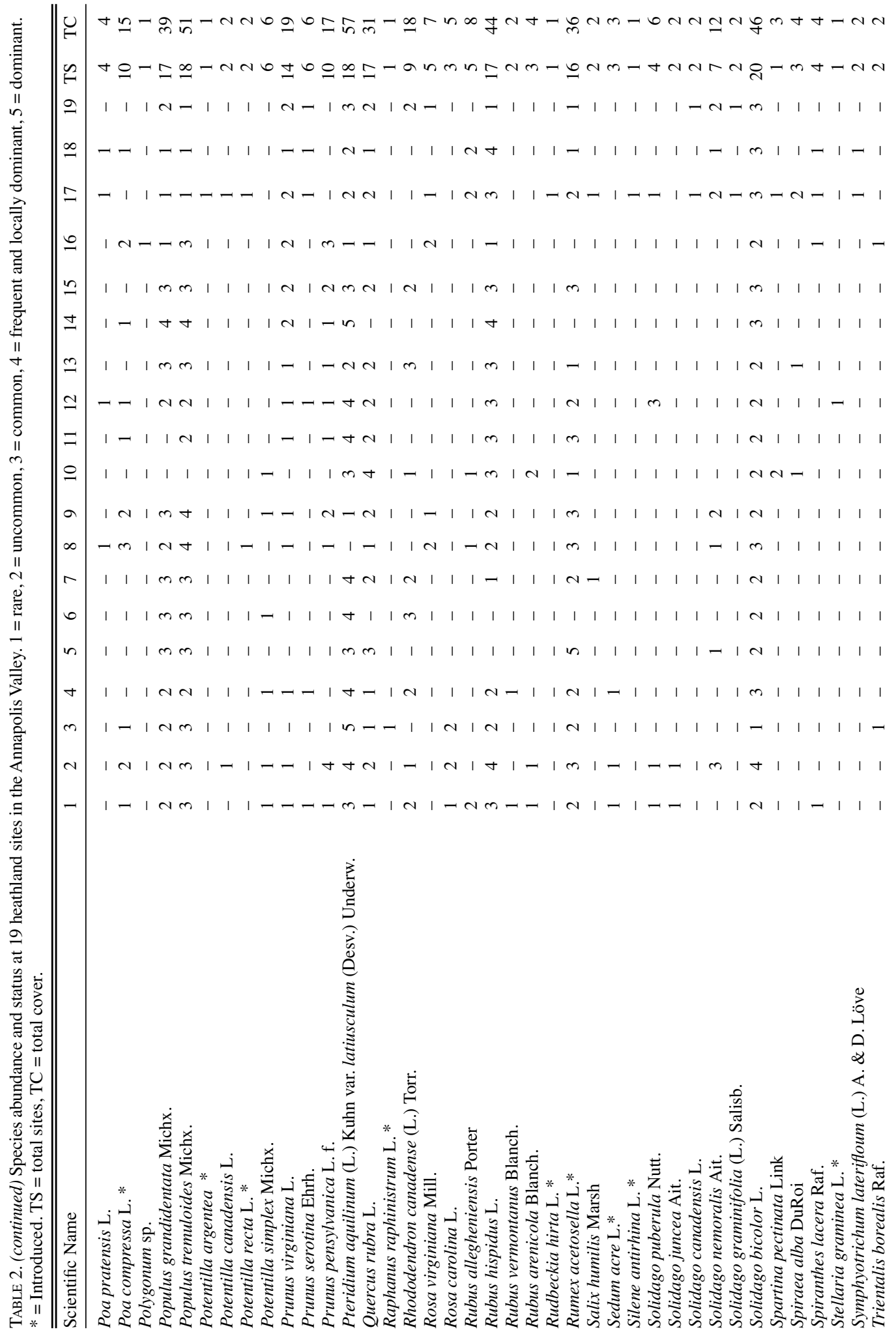




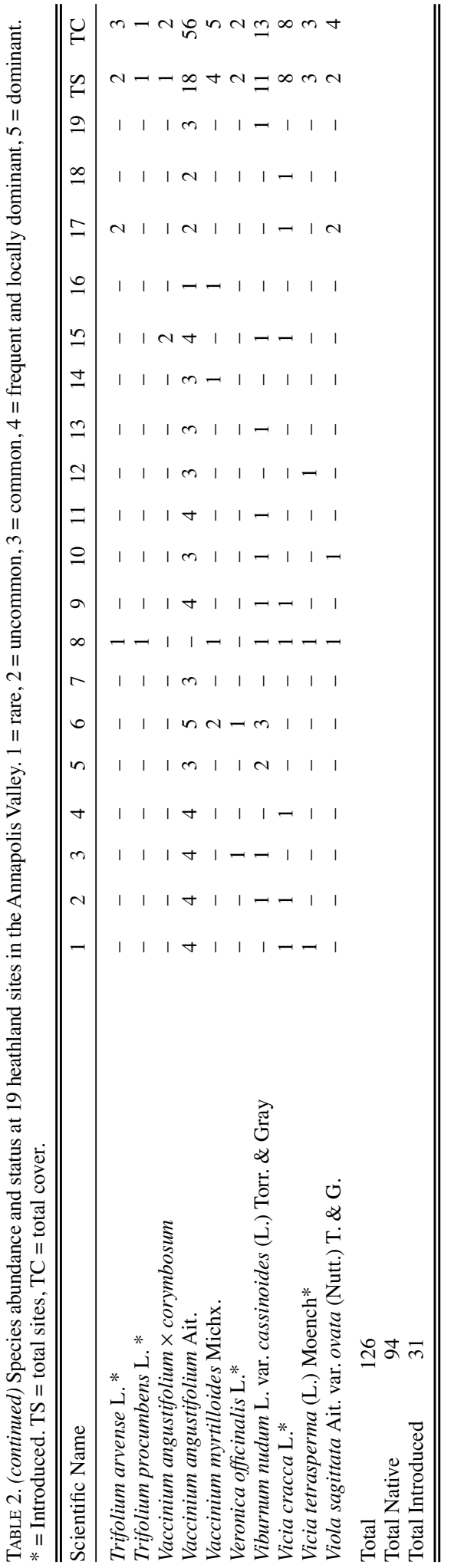

tion of the Annapolis sand barren flora, the mesic and successional stages of dry barrens are to a large extent omitted. This may explain the lack of some species in the survey, such as Agalinis neoscotica (Greene) Fern. (Middleton False Foxglove), which was described from Annapolis heathlands near Middleton, and also Bartonia virginica (L.) BSP., Carex atlantica, Polygala sanguinea L. and Sisyrinchium fuscatum Bickn. All of these species occur on heathlands near Middleton (personal observation), but were not seen during the present survey. Their abundance in the area in the past (Fernald 1921, page 138) suggests that the more mesic and naturally disturbed areas were much more prevalent only a short time ago. Fernald (1921) referred to these as the "the damper Polytrichim-carpeted areas." He noted that "Bartonia virginica was everywhere," but it was not recorded in any of the barrens in our survey and only our site 10 approached this damper sand barrens habitat.

In addition to the lack of mesic sites it is of interest that in two days in 1920 Fernald (1921) recorded two species from the drier heathlands near Middleton that were not seen by us. These were Potentilla tridentata and Pyrola rotundifolia. Although our data indicate the general and dominant composition of the Annapolis heathlands, the differences with Fernald's brief survey suggest that it may never be possible to have a complete knowledge of their former floristc composition.

\section{Dominant vascular plants}

Relatively few of the 126 species (94 were native and 31 introduced - Table 2) present in the 19 completely surveyed sites were dominant in the vegetation. Species present at all sites included Corema conradii, Danthonia spicata, Pinus strobus and Solidago bicolor. Species present at 18 of the 19 sites were Amelanchier laevis, Carex tonsa var. rugosperma, Comptonia peregina, Dichanthelium depauperatum, Pteridium aquilinum var. latiusculum, Vaccinium angustifolium and Populus tremuloides. Species with the highest overall cover values included Corema conradii with 91 followed by Comptonia peregrina with 59, Pteridium acquilinum var. latiusculum with 57, and Vaccinium angustifolium with 56. A number of species, including Solidago bicolor, Carex tonsa var. rugosperma, Dichanthelium depauperatum, Lechea intermedia, Melampyrum lineare and Rubus hispidus, were characteristic of heathland remnants, although they were rarely dominant. The most frequent alien species were Hieracium pilosella and Festuca filiformis, both at 17 and 16 (respectively) of 19 sites. The most serious invasive of the heathlands in terms of displacing native species was Pinus sylvestris, present at 8 sites (Catling and Carbyn 2004).

The more wooded plot sites (20-23) gave a very similar picture of the Corema-dominated heathland, but with scattered trees, mostly Pinus resinosa (Table 3, Figure 3). Three species more often associated with woodland than with barrens (Clintonia borealis, Lyco- 
TABLE 3. Cover values for vegetation layers in single 400 square meter plots at each of 4 sites in the Annapolis valley, based on data collected by Sean Basquill in May 2005. * = introduced, $+=$ not listed in Table 2.

\begin{tabular}{|c|c|c|c|c|}
\hline Species & Site 20 & Site 21 & Site 22 & Site 23 \\
\hline \multicolumn{5}{|l|}{ Trees } \\
\hline Amelanchier laevis Wieg. & 2 & - & - & - \\
\hline Betula populifolia Marsh & 3 & 2 & 5 & 5 \\
\hline Picea mariana (P. Mill.) B.S.P. & - & - & 5 & - \\
\hline Pinus resinosa Ait. & 20 & 25 & 20 & 10 \\
\hline Pinus strobus L. & - & - & 5 & 8 \\
\hline Pinus sylvestris L. * & - & - & - & 10 \\
\hline Prunus pensylvanica L. f. & - & 1 & - & - \\
\hline Quercus rubra $\mathrm{L}$. & - & 4 & 0.1 & - \\
\hline \multicolumn{5}{|l|}{ Shrubs and small trees } \\
\hline Amelanchier laevis Wieg. & - & - & 0.1 & 0.2 \\
\hline Betula populifolia Marsh & 3 & 2 & 5.1 & 3 \\
\hline Comptonia peregrina (L.) Coult. & 1 & 1 & - & - \\
\hline Juniperus communis L. var. depressa Pursh & - & - & - & 0.1 \\
\hline Picea mariana (P. Mill.) B.S.P. & - & 0.1 & - & - \\
\hline Pinus resinosa Ait. & 4 & 4 & 1 & 1 \\
\hline Pinus strobus L. & 0.5 & - & 1 & 5 \\
\hline Pinus sylvestris L. * & - & - & - & 5 \\
\hline Quercus rubra L. & - & 1 & - & - \\
\hline Vaccinium angustifolium Ait. & 0.1 & 0.5 & 3 & 6 \\
\hline \multicolumn{5}{|l|}{ Herbs and dwarf shrubs } \\
\hline Arctostaphylos uva-ursi (L.) Spreng. & 30 & 5 & 10 & 8 \\
\hline Betula populifolia Marsh & - & - & 0.2 & - \\
\hline Carex tonsa (Fern.) Bickn. (sensu lato) & 0.01 & 0.1 & 1 & 1 \\
\hline Clintonia borealis (Ait.) Raf. + & - & - & 0.01 & - \\
\hline Corema conradii (Torr.) Torr. ex Loud. & 58 & 40 & 60 & 60 \\
\hline Deschampsia flexuosa (L.) Trin. & - & - & 1 & 1 \\
\hline Dichanthelium depauperatum (Muhl.) Gould & - & - & 0.1 & - \\
\hline Epigaea repens $\mathrm{L}$. & - & - & 0.01 & 0.1 \\
\hline Festuca filiformis Pourret* & 0.1 & - & 0.01 & 0.5 \\
\hline Festuca trachyphylla (Hackel) Krajina * & - & 0.001 & - & - \\
\hline Gaultheria procumbens L. & 0.5 & 0.01 & - & - \\
\hline Hieracium piloselloides Vill. * & - & - & 0.01 & - \\
\hline Hudsonia ericoides $\mathrm{L}$. & 0.01 & 0.1 & - & 0.3 \\
\hline Kalmia angustifolia $\mathrm{L}$. & 0.1 & 0.01 & - & - \\
\hline Lechea intermedia Leggett & 0.001 & - & - & - \\
\hline Lycopodium obscurum L. + & - & - & 0.1 & - \\
\hline Lycopodium tristachyum Pursh & 0.1 & 0.01 & - & - \\
\hline Maianthemum canadense Desf. & - & - & 0.01 & - \\
\hline Oryzopsis asperifolia Michx. + & - & 0.1 & 0.2 & - \\
\hline Poa pratensis $\mathrm{L}$. & - & 0.1 & 0.1 & 0.1 \\
\hline Potentilla simplex Michx. & - & - & - & 0.2 \\
\hline \multicolumn{5}{|l|}{ Pteridium aquilinum (L.) Kuhn } \\
\hline var. latiusculum (Desv.) Underw. & 10 & 1 & 0.02 & - \\
\hline Rubus hispidus $\mathrm{L}$. & - & 0.001 & - & 0.01 \\
\hline Solidago bicolor $\mathrm{L}$. & - & 0.2 & - & - \\
\hline Solidago nemoralis Ait. & - & 0.001 & 0.2 & 0.1 \\
\hline Taraxacum officinale G. H. Weber ex Wiggers & - & - & 0.002 & - \\
\hline Trientalis borealis Raf. & 0.01 & - & 0.01 & - \\
\hline Vaccinium angustifolium Ait. & - & - & - & 0.01 \\
\hline \multicolumn{5}{|l|}{ Mosses } \\
\hline Ceratodon purpureus (Hedw.) Brid.+ & - & 0.001 & - & 2 \\
\hline Dicranum scoparium Hedw.t & - & 1 & - & - \\
\hline Pleurozium schreberi (Brid.) Mitt.+ & 0.5 & 0.1 & 0.5 & - \\
\hline Polytrichum commune Hedw.+ & - & - & 0.1 & 1 \\
\hline Polytrichum juniperinum Hedw.+ & - & 0.01 & 0.3 & 3 \\
\hline \multicolumn{5}{|l|}{ Lichens } \\
\hline Cladina rangiferina (L.) Nyl.+ & 18 & 40 & 7 & 10 \\
\hline Cladina stellaris (Opiz) Brodo + & 2 & 10 & 3 & 5 \\
\hline
\end{tabular}




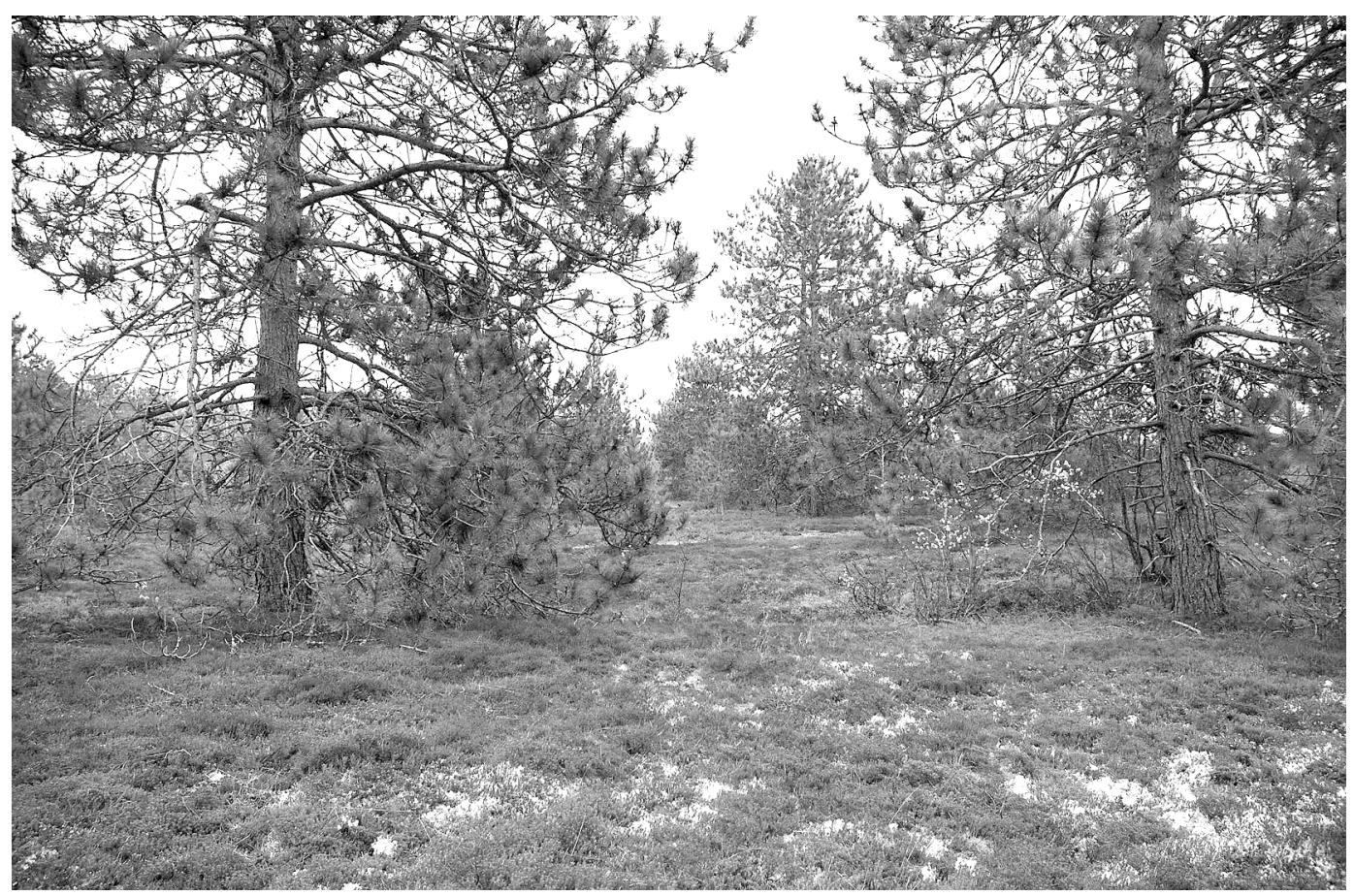

FIGURE 3. Open wooded heathland dominated by Corema conradii and Cladina rangiferina with scattered Pinus resinosa. Although there is much open area, the site exceeds the threshold $10 \%$ tree cover required for classification as a treed association under Canadian vegetation classification conventions (CNVC Technical Committee 2004*). Photo by S. Basquill on 25 May 2005 at site 20.

podium obscurum and Oryzopsis asperifolia) were present a these more wooded sites. Although vascular plants were the focus of the descriptive work, the plot data included lichens and bryophytes, suggesting the former (Cladina rangiferina and C. stellaris) to be a significant component. This suggestion is supported by general observations at the 19 other sites where quantitative data on bryophytes and lichens was not obtained.

Although Roland (1946) described the Annapolis sand barrens and heathlands 60 years ago, his description, which recorded 35 species, corresponds very closely to the composition seen in the relicts that remain today. The successional processes are possibly also the same as described generally by Roland, but succession may have been much more rapid in some areas than in others where barrens and heathlands may have existed as a subclimax lasting for centuries, even without fire. Roland's article was written at a time when sand barrens, heathlands and savanna were regarded as wasteland rather than as special places for native biodiversity, but his strong forestry theme is accompanied by many astute observations regarding the native flora. At the time of early settlement the barrens and heathlands may have expanded due to cutting and burning of pine forests and abandonment of sandy land cleared for agriculture as suggested by Roland. However there is little doubt that they also existed in presettlement times.

\section{Rare and significant species}

The only species considered to be at risk in Nova Scotia that occurs in the Annapolis heathlands is Helianthemum canadense (Long-Branch Frostweed, Figure 4). It was found at 6 of the sites, always in disturbed habitats with some bare sand. Both Viola sagittata var. ovata and Hudsonia ericoides are listed as sensitive (Nova Scotia Department of Natural Resources $2001 \%$ ), and these also occurred in disturbed sandy areas (Figure 5). The provincially rare (Maher et al. 1978) Sisyrinchium fuscatum Bickn. (CoastalPlain Blue-Eyed-Grass) was reported from "sandy areas near Middleton" (sub Sisyrinchium arenicola Bickn., Roland and Smith 1969), but was not seen during the present survey.

In addition to the rare and threatened species there is a suggestion of some distinctive patterns of variation due to taxonomic recognition of several variants. Among these is a sand barren ecotype of Amelanchier lucida (personal observation). Taxa of blackberries (Rubus particeps, R. arenicola), although not recognized as discrete in some recent literature, have been reported from the Annapolis heathlands suggesting at 
least the presence of distinctive genetic variants within broadly defined species. Further study may indicate both of these to be worthy of taxonomic recognition. A restricted glabrous variant of Viola sagittata var. ovata (f. glabrata) occurs on the dry open sand with the more typical form. Three taxa have been described from Annapolis heathlands: Amelanchier lucida Fernald, Dichanthelium (sub Panicum) depauperatum var. psilophyllum f. cryptostachys Fernald, and Rubus particeps Bailey.

The heathland ecosystem is particularly valuable as a reservoir of genetic variation in crops and crop relatives. Fernald (1921) commented on the remarkable variation in wild blueberries (Vaccinium angustifolium and V.myrtilloides) in Annapolis heathland remnants near Middleton. In addition to blueberries (Table 2) there are potential genotypes of Aronia (Aronia sp.), of blackberries (Rubus hispidus and others), juneberries (Amelanchier lucida and A. laevis), huckleberries (Gaylussacia baccata and G. dumosa), cherries (Prunus pensylvanica, $P$. virginiana, and $P$. serotina) and a strawberry (Fragaria virginiana).

\section{Variation between sites}

Although all sites shared dominant species (Table 2) they varied in diversity from 26 to 57 native species. Much of the variation between sites appeared to be attributable to disturbance and soil moisture. Those sites with lower lying and periodic moist areas and open sand had the highest vascular plant diversity. Site 10 for example was the most unlike the other sites in native species composition, possibly a result of parts of it having a relatively high water table and disturbed areas of periodically moist sand where dry ground species such as Carex tonsa var. rugosperma and Danthonia spicata occurred with wetland species such as Drosera intermedia.

Characteristic native species and "at risk" or "sensitive" species were present at some sites but absent from others (Table 2). Sites also varied in the extent to which alien species were present and dominant (Table 2). For example parts of sites 1 and 4 had extensive and spreading stands of Pinus sylvestris, but displacement of native vegetation by this introduced tree was either less extensive or not observed at other sites. Festuca filiformis was a co-dominant at site 5 but not elsewhere.

Species presence, diversity and extent of impacts all require consideration in selecting sites for protection. The variation between sites in composition and abundance, including that of rare and/or characteristic species, suggests that protection of a number of sites will be necessary to protect representative ecosystem components.

\section{Relationship to other heathlands and barrens}

In Canada, Corema-dominated barrens are characteristic of the maritime region. Corema conradii has a restricted distribution extending from the Gulf of

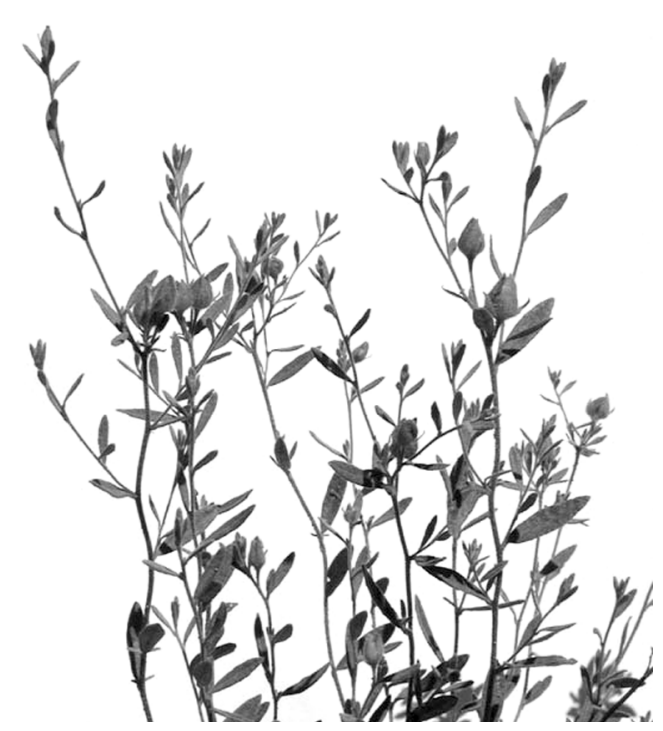

FIGURE 4. Helianthemum canadense (Long-Branch Frostweed), a native plant at risk in Nova Scotia, with its main Nova Scotian occurrence on the Annapolis valley heathlands. Photo by P. M. Catling in 2004 at site 8 .

St. Lawrence region south to New Jersey. It does not occur in sand barrens further to the west in Canada, for example in the Ottawa valley, where Vaccinium angustifolium is the dominant heath shrub accompanied by other shrubs such as Prunus susquehanae and Comptonia peregina (Carbyn and Catling 1995). Other species present in the Annapolis heathlands but absent in Ottawa valley sites were Amelanchier lucida, Deschampsia flexuosa, Rubus hispidus and Solidago bicolor. Among the prevalent species in Ottawa valley sand barrens but absent in the Annapolis sites were Carex siccata, Carex lucorum, Dichanthelium sabulorum var. thinium, Polygonella articulata and Prunus susquehanae (Carbyn and Catling 1995).

Within Nova Scotia, "barrens" with heath vegetation occupied a large part of the western portion of the province (Strang 1972). Some of these barrens are a short-lived successional stage following fire, whereas in other cases they are long persisting. Those of short duration have in some cases been produced by cutting and then maintained by fires. Two such barrens were described by Hall and Aalders (1968). Such barrens, produced by human activities, have been considered a degraded landscape of little economic value. The existence and importance of apparently natural barrens have only recently become apparent (Catling et al. 2004). The sites described by Hall and Aalders (1968) differ from those in the Annapolis Valley in lacking Corema conradii, the dominant of the Annapolis barrens. They were also without several other species, including Hudsonia ericoides. On this basis the differences between man-made and natural barrens seem 


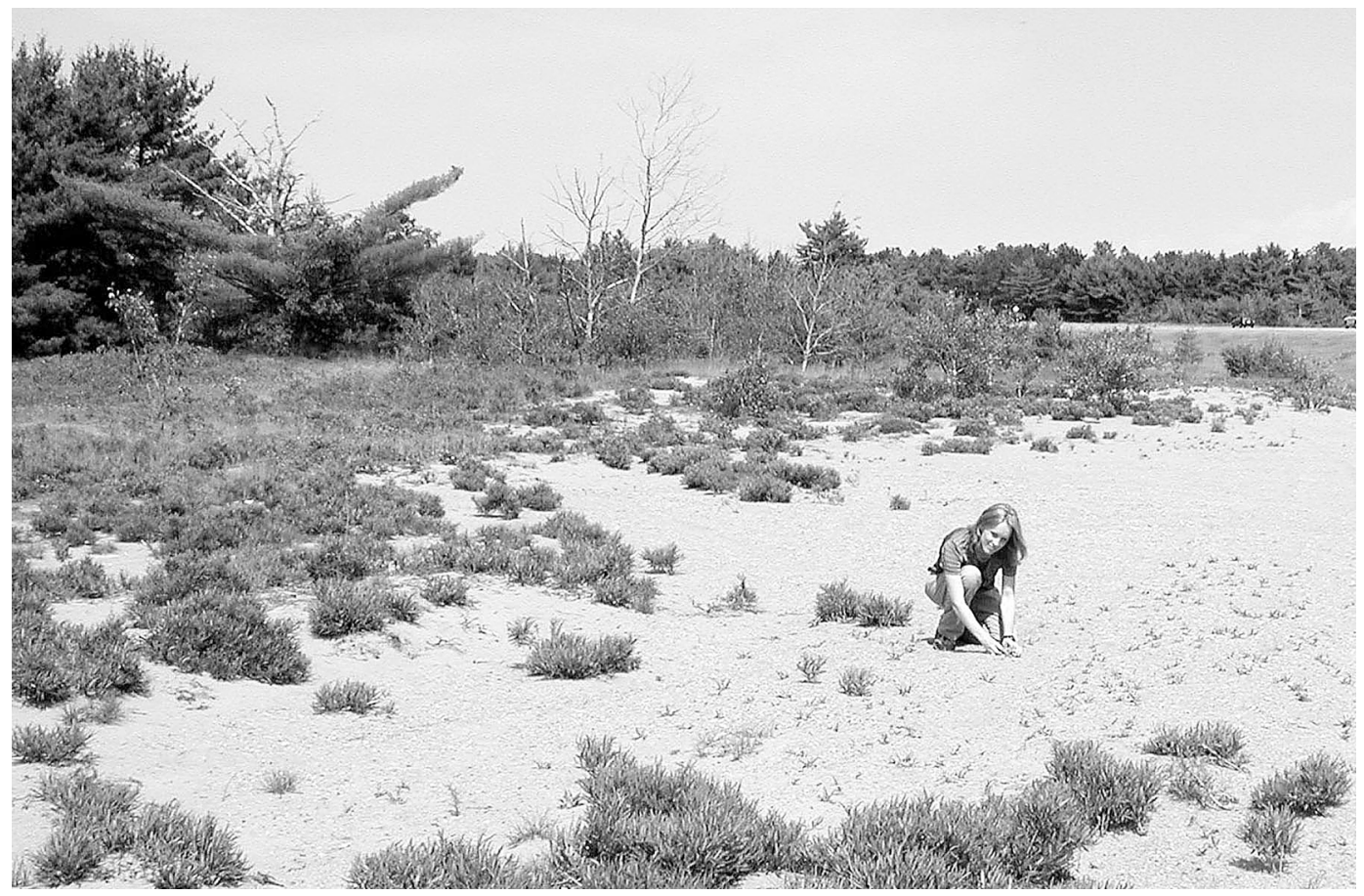

FIGURE 5. Open sandy ground in a disturbed area of heathland with Comptonia peregrina (Sweet Fern) and Viola sagittata var. ovata (Arrow-leaved Violet). Photo by P. M. Catling in 2004 at site 8.

pronounced, but with only two anthropogenic sites, a more detailed comparison is unnecessary.

The apparently longer persisting natural barrens in Nova Scotia are readily divided into two major vegetation types based on either granitic or sandy substrates (personal observation). Sandy heathlands like those of the Annapolis Valley were also well developed in the interior of Yarmouth County and near Debert, Springhill, Parrsboro, and on coastal dunes in Guysborough and Kings counties and on Sable Island. The coastal heathlands on sand differ from the interior sites in both species composition and species abundance, and the differences suggest adaptation to different conditions. Differences also exist at the infraspecific level. For example Lechea intermedia var. intermedia occurs in interior heathlands while $L$. intermedia var. juniperina occurs on the coastal sandy heathlands. The heathlands on Sable Island appear distinct (Catling et al. 1985). The interior sandy heathlands also appear to vary regionally, presumably due to differences in climate. The climate in southern Yarmouth and Shelburne differs from that of the Annapolis Valley (personal observation). The data suggest that the Annapolis heathlands are distinctive in their floristic composition.

\section{Acknowledgments}

Mark F. Elderkin, Species at Risk biologist with the Nova Scotia Department of Natural Resources, assisted with current information on status ranks. Lawrence Benjamin and Randy Milton, also of the Nova Scotia Department of Natural Resources, provided information on site locations for rare plant species in the Annapolis Valley. Steve Javorek and M. Grant assisted with field studies (site 1). Geoff Mercer assisted with the inventory of sites on military bases at Aldershot (site 14) and Greenwood (sites 17 and 18).

Documents Cited (marked * in text)

CNVC Technical Committee. 2004. Plant association concept for the Canadian National Vegetation Classification. NatureServe Canada. 5 pages. http://www.cnvc-cnvc.ca.

Esslinger, T. L. 1997. A cumulative checklist for the lichenforming, lichenicolous and allied fungi of the continental United States and Canada. North Dakota State University: http://www.ndsu.nodak.edu/instruct/esslinge/chcklst/ chcklst7.htm

Nova Scotia Department of Natural Resources. 2001. General status ranks of wild species. Vascular plants. http:// www.gov.ns.ca/natr/wildlife/genstatus/specieslist.asp

Quigley, E., P. Neily, K. Keys, and B. Stewart. 2005. Nova Scotia Department of Natural Resources Forest Ecosystem Classification; Methods for Plot Establishment and Vegetation Inventory. Unpublished Internal Document.

\section{Literature Cited}

Anderson, L. E., H. A. Crum, and W. R. Buck. 1990. List of the mosses of North America north of Mexico. Bryologist 93: 448-499. 
Carbyn, S. E., and P. M. Catling. 1995. Vascular flora of sand barrens in the middle Ottawa valley. Canadian FieldNaturalist 109: 242-250.

Catling, P. M., and S. Carbyn. 2004. Invasive Scots Pine (Pinus sylvestris) replacing Corema heathland in the Annapolis valley. Canadian Field-Naturalist 119(2): 237-244.

Catling, P. M., S. Carbyn, S. P. Vander Kloet, K. MacKenzie, S. Javorek, and M. Grant. 2004. Saving Annapolis Heathlands. Canadian Botanical Association Bulletin 37(1): 12-14.

Catling, P. M., B. Freedman, and Z. Lucas. 1985. Vegetation and phytogeography of Sable Island, Nova Scotia. Proceedings of the Nova Scotia Institute of Science 24: 181-248.

Fernald, M. L. 1921. The Gray Herbarium expedition to Nova Scotia. Rhodora 23: 130-171.

Hall, I. V., and L. E. Aalders. 1968. The botanical composition of two barrens in Nova Scotia. Le Naturaliste canadien 95: 393-396.
Kartesz, J. T., and C. A. Meachum. 1999. Synthesis of the North American Flora, version 1.0. North Carolina Botanical Garden, Chapel Hill, North Carolina.

Maher, R. V., D. J. White, G. W. Argus, and P. Keddy. 1978. The rare vascular plants of Nova Scotia. Syllogeus (National Museums of Canada, Ottawa) 18.37 pages.

Roland. A. 1946. The vegetation of the Annapolis valley I. - well drained sand areas. Acadian Naturalist 2(7): 1-20.

Roland, A. E., and E. C. Smith. 1969. The flora of Nova Scotia. Nova Scotia Museum. Reprinted from Proceedings of the Nova Scotian Institute of Science 26: 1-238, 277743.

Strang, R. M. 1972. Ecology and land use of the barrens of western Nova Scotia. Canadian Journal of Forest Research 2: 276-290.

Received 25 September 2005

Accepted 17 February 2007 